\title{
Evaluation of quality of life in multiple sclerosis patients: impact of fatigue, anxiety and depression
}

\author{
Avaliação da qualidade de vida em portadores de esclerose múltipla: impacto da fadiga, \\ ansiedade e depressão
Evaluación de la calidad de vida en portadores de esclerosis múltiple: impacto de la fatiga, ansiedad y depresión

Maria da Conceição Nascimento da Silva', Dominique Babini Albuquerque Cavalcanti²

\begin{abstract}
I This study aims to assess the perception of quality of life in patients with multiple sclerosis (MS) and to verify if there is an association with fatigue, anxiety and depression. This is a cross-sectional study with a sample composed by 100 individuals with a diagnosis of MS enrolled in the Centro de Referência para Atenção ao Paciente Portador de Doença Desmielinizante do Hospital da Restauração. The Functional Determination Scale for Quality of Life in Multiple Sclerosis (DEFU), the Modified Fatigue Impact Scale (MFIS-BR), and the Hospital Anxiety (HADS-S) and Depression Scale (HADS-D) were applied. Patients with a Primary progressive clinical form presented worse perception of quality of life $(66.90 \pm 3.47)$ when compared to the Secondary progressive $(71.65 \pm 5.92)$ and Relapse-remitting $(79.00 \pm 6.62)$ forms, with Significant difference $(p<0.001)$. There was a strong positive correlation between the DEFU and the MFIS-BR scores ( $r=0.84$ ), and a strong negative correlation between DEFU and HADS-A $(r=-0.85)$, and DEFU and HADS-D ( $r=-0.82)$. The decrease in the perception of quality of life in patients with multiple sclerosis is more critical in progressive forms of the disease and is associated with the presence of fatigue, depression and anxiety.
\end{abstract}

Keywords | Multiple Sclerosis; Quality of Life; Fatigue; Depression; Anxiety.

RESUMO I O objetivo do estudo foi avaliar a percepção da qualidade de vida em pacientes com esclerose múltipla (EM) e verificar se há associação com fadiga, ansiedade e depressão. Trata-se de um estudo transversal com amostra composta por 100 indivíduos com diagnóstico de EM cadastrados no Centro de Referência para Atenção ao Paciente Portador de Doença Desmielinizante do Hospital da Restauração. Foram aplicadas: a escala de determinação funcional da qualidade de vida na EM (Defu), a escala modificada do impacto da fadiga (MFIS-BR) e a escala hospitalar de ansiedade (HAD-a) e depressão (HAD-d). Os pacientes com a forma clínica primariamente progressiva apresentaram pior percepção da qualidade de vida $(66,90 \pm 3,47)$ quando comparados às formas secundariamente progressivas $(71,65 \pm 5,92)$ e remitente-recorrente $(79,00 \pm 6,62)$, com diferença estatística significativa $(p<0,001)$. Houve forte correlação positiva entre os escores da Defu e da MFIS-BR $(r=0,84)$, e forte correlação negativa entre Defu e HAD-a $(r=-0,85)$ e Defu e HAD-d ( $r=-0,82)$. A diminuição da percepção da qualidade de vida em pacientes com EM é mais crítica nas formas progressivas da doença e tem associação com a presença de fadiga, depressão e ansiedade.

Descritores | Esclerose Múltipla; Qualidade de Vida; Fadiga; Depressão; Ansiedade.

RESUMEN | El objetivo del estudio fue evaluar la percepción de calidad de vida en pacientes con esclerosis múltiple (EM) y verificar si existe una asociación con fatiga, ansiedad y depresión. Este es un estudio transversal con una muestra de 100 individuos diagnosticados con EM, registrados en el Centro de Referencia para Atención al Paciente con Enfermedades Desmielinizantes en el Hospital da Restauração. Aplicamos: la Escala de Determinación Funcional de Calidad de Vida en

'Centro Universitário Maurício de Nassau (Uninassau) - Recife (PE), Brazil. E-mail: conceicaomnascimento@hotmail.com. Orcid: 0000-0003-4422-1211

${ }^{2}$ Centro Universitário Maurício de Nassau (Uninassau) - Recife (PE), Brazil. E-mail: dbabini.fisioterapeuta@gmail.com. Orcid: 0000-0003-0997-0663 
EM (Defu), la Escala de Impacto de Fatiga Modificada (MFIS-BR) y la Escala de Ansiedad Hospitalaria (HAD-a) y Depresión (HAD-d). Los pacientes con la forma clínica primaria progresiva tenían una peor percepción de la calidad de vida $(66,90 \pm 3,47)$ en comparación con la forma secundaria progresiva $(71,65 \pm 5,92)$ y recurrente-remitente $(79,00 \pm 6,62)$, con una diferencia estadísticamente significativa $(p<0,001)$. Hubo una fuerte correlación positiva entre los puntajes
Defu y MFIS-BR $(r=0,84)$, y una fuerte correlación negativa entre Defu y HAD-a $(r=-0,85)$ y Defu y HAD-d $(r=-0,82)$. La disminución de la percepción de la calidad de vida en pacientes con EM es más crítica en las formas progresivas de la enfermedad y se asocia con la presencia de fatiga, depresión y ansiedad.

Palabras clave | Esclerosis Múltiple; Calidad de Vida; Fatiga; Depresión; Ansiedad.

\section{INTRODUCTION}

Considered the most common demyelinating disorder of the central nervous system, multiple sclerosis (MS) is characterized by repeated episodes of neurological dysfunction with variable remission ${ }^{1}$. This disease is presented under three main types: Relapse-remitting (RRMS), Secondary progressive (SPMS) and Primary progressive (PPMS) ${ }^{2}$.

In the case of RRMS, the individual presents clearly defined outbreaks with complete or incomplete remission, maintaining periods without progression between outbreaks. In SPMS, the individual presents an initial process type RRMS, which is subsequently succeeded by progression with or without occasional outbreaks, discrete remissions and plateaus. And in PPMS, the individual presents a progressive process from the beginning, with occasional plateaus and/or discrete fluctuations ${ }^{3}$.

The disease and the side effects of medications impact negatively in the health and well-being of these individuals, interfering in their quality of life $(\mathrm{QoL})^{4}$. According to the World Health Organization, QoL is defined as the individual's perception of their position in life, in the cultural context and in the system of values in which they live and in relation to their goals, expectations, standards and desires ${ }^{5}$. In the biomedical area, healthrelated quality of life (HRQoL) refers to satisfaction regarding health status, a combination of health status and affective response to this condition ${ }^{6}$. Among the groups of chronic patients, HRQoL is used to compare its relationship with the physical and psychological disabilities caused by these diseases and to assess the effects of certain types of treatments ${ }^{7}$.

The MS triggers a set of very common damage, as fatigue $^{8}$, pain ${ }^{9}$ and alterations of motricity and sensitivity ${ }^{3}$, being the fatigue the most frequent and disabling symptom of the disease ${ }^{10}$, occur in $75 \%$ to $96 \%$ of disease carriers ${ }^{11}$. In Brazil, it is estimated that between $66.7 \%$ and $86.7 \%$ of the carriers present this condition ${ }^{12}$. The impact of this symptom highlights the importance of its assessment and diagnosis ${ }^{13}$.

Among the set of psychological complications originating in MS the depression is one of the most common symptoms ${ }^{14}$. This illness affects between $27 \%$ and $54 \%$ of patients, although lower rates have been estimated, and symptoms are described as moderate or severe $^{15}$. In a Canadian multicenter study, with 3,125 patients, it was observed that depression rate is 7.5 times greater than that of the general population for the same age, and suicidal ideation is present in $28.6 \%$ of patients with $\mathrm{MS}^{16}$.

Anxiety in patients with MS also tends to present higher scores in anxiety assessment scales when compared to anxious patients who do not have this disease ${ }^{17}$. Fear of pain, disability and unpredictability of this disease can intensify anxiety symptoms ${ }^{18}$.

The study aims to assess the perception of QoL in patients with MS and to verify if the disease is associated with fatigue, anxiety and depression.

\section{METHODOLOGY}

Cross-sectional study whose sample was compose by 100 individuals diagnosed with MS registered in the Centro de Referência para Atenção ao Paciente Portador de Doença Desmielinizante do Hospital da Restauração (CRAPPDD/HR), located in Recife (PE), in the period between May, 2014 and April, 2016.

The inclusion criteria for the study were: patients aged 18 years or older, clinical diagnosis of MS confirmed by neurologist, and registration at CRAPPDD/HR. The exclusion criteria were: schooling below four years, presence of other associated neurological diseases, use of antidepressants and/or anti-anxiety medications in the last three months, use of immunotherapy or 
immunosuppressive drugs, an antecedent of abusive use of drugs and alcohol, refusal to participate in the study.

Personal, socioeconomic, and clinical data of the disease were collected. The sample characterization is presented in Table 1, according to the clinical forms of the disease. There was a predominance of RRMS cases (60\%). The SPMS and PPMS forms represented equally $40 \%$ of the remaining cases. The mean age of patients with PPMS at the onset of signs and symptoms was higher than in the RRMS and SPMS groups $(\mathrm{p}<0.001)$.

Table 1. Characterization of patients with MS by clinical form of the disease

\begin{tabular}{|c|c|c|c|c|}
\hline \multirow{3}{*}{ Characterization } & \multicolumn{3}{|c|}{ Clinical form of the disease } & \multirow[b]{3}{*}{ p-value* } \\
\hline & RRMS & SPMS & PPMS & \\
\hline & Mean \pm SD & Mean $\pm S D$ & Mean \pm SD & \\
\hline $\begin{array}{l}\text { Current Age } \\
\text { Age at onset of symptoms }\end{array}$ & $\begin{array}{r}37.58 \pm 2.55 \\
29.56 \pm 2.36\end{array}$ & $\begin{array}{l}40.45 \pm 3.73 \\
29.46 \pm 2.46\end{array}$ & $\begin{array}{l}41.65 \pm 4.06 \\
34.60 \pm 2.03\end{array}$ & $\begin{array}{l}<0.001^{a, b} \\
<0.001^{b, c}\end{array}$ \\
\hline & No. (\%) & No. (\%) & No. (\%) & p-value** \\
\hline $\begin{array}{l}\text { Sex } \\
\text { Female } \\
\text { Male }\end{array}$ & $\begin{array}{r}47(78.3) \\
13(21.7)\end{array}$ & $\begin{array}{r}15(75.0) \\
5(25.0)\end{array}$ & $\begin{array}{r}16(80.0) \\
4(20.0)\end{array}$ & 0.925 \\
\hline $\begin{array}{l}\text { Race } \\
\text { White } \\
\text { Brown } \\
\text { Black }\end{array}$ & $\begin{array}{r}15(25.0) \\
40(66.7) \\
5(8.3)\end{array}$ & $\begin{array}{r}5(25.0) \\
13(65.0) \\
2(10.0)\end{array}$ & $\begin{array}{r}6(30.0) \\
12(60.0) \\
2(10.0)\end{array}$ & 0.988 \\
\hline $\begin{array}{l}\text { Marital status } \\
\text { Single } \\
\text { Married } \\
\text { Divorced }\end{array}$ & $\begin{array}{r}24(40.0) \\
30(50.0) \\
6(10.0)\end{array}$ & $\begin{array}{r}8(40.0) \\
10(50.0) \\
2(10.0)\end{array}$ & $\begin{array}{l}9(45.0) \\
9(45.0) \\
2(10.0)\end{array}$ & 0.996 \\
\hline $\begin{array}{l}\text { Schooling } \\
\text { Elementary school } \\
\text { High school } \\
\text { Higher education }\end{array}$ & $\begin{array}{r}14(23.3) \\
36(60.0) \\
10(16.7)\end{array}$ & $\begin{array}{r}5(25.0) \\
13(65.0) \\
2(10.0)\end{array}$ & $\begin{array}{r}6(30.0) \\
11(55.0) \\
3(15.0)\end{array}$ & 0.928 \\
\hline
\end{tabular}

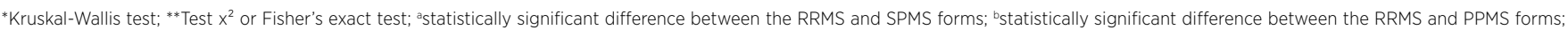
'statistically significant difference between SPMS and PPMS forms; RRMS: Relapse-remitting multiple sclerosis; SPMS: Secondary progressive multiple sclerosis; PPMS: Primary progressive multiple sclerosis; SD: Standard deviation; No.: Frequency.

Spinal cord symptoms/initial signs were more common in individuals with the PPMS clinical form ( $p=0.003$ ) compared to the RRMS and SPMS forms. No statistically significant difference was recorded for the other initial and evolutionary symptoms/signs (Table 2).

Then, the patients responded to a version of the Functional Assessment of Multiple Sclerosis (FAMS) scale, translated and validated for the Portuguese language named DEFU (Determinação Funcional de Qualidade de Vida), composed by 44 items divided into 6 domains valid for analysis: mobility, symptoms, emotional well-being, general contentment, thinking and fatigue, and family/social well-being. Higher scores reflect better QoL. The 5 domains with 7 items allow scores ranging between 0 and 28; the domain with 9 items (thinking and fatigue) has its scores ranging between 0 and 36 , and the total score varies from 0 to $176^{19}$.

The Modified Fatigue Impact Scale (Escala Modificada do Impacto da Fadiga - MFIS-BR) was also used in the translated version to Portuguese and validated for the Brazilian population. The instrument is composed by 21 items stratified in three subscales: physical, cognitive and psychosocial subscales. The total score is given by the sum of the three subscales and ranges between 0 and 84; values below 38 correspond to the absence of fatigue, and values above represent the presence of fatigue ${ }^{20}$.

Table 2. Presence of initial and evolutionary symptoms/signs for each clinical form of the disease

\begin{tabular}{lrrrr} 
& \multicolumn{3}{c}{ Clinical form of the disease } & \\
\cline { 2 - 4 } Symptoms and Signs & \multicolumn{1}{c}{ RRMS } & SPMS & PPMS & \\
\cline { 2 - 4 } & No. (\%) & No. (\%) & No. (\%) & p-value* \\
Initial & & & & \\
Pyramidal & $7(11.7)$ & $3(15.0)$ & $3(15.0)$ & 0.889 \\
Spinal cord-related & $12(20.0)$ & $5(25.0)$ & $12(60.0)$ & $0.003^{a, b}$ \\
Optic & $11(18.3)$ & $6(30.0)$ & $1(5.0)$ & 0.120 \\
Sensory & $18(30.0)$ & $2(10.0)$ & $1(5.0)$ & 0.090 \\
Torso & $7(11.7)$ & $3(15.0)$ & $1(5.0)$ & 0.580 \\
Cerebellar & $5(8.3)$ & $2(10.0)$ & $1(5.0)$ & 0.834 \\
Evolutionary & & & & \\
Pyramidal & $36(60.0)$ & $11(55.0)$ & $11(55.0)$ & 0.884 \\
Spinal cord-related & $41(68.3)$ & $15(75.0)$ & $16(80.0)$ & 0.570 \\
Optic & $30(50.0)$ & $11(55.0)$ & $7(35.0)$ & 0.398 \\
Sensory & $32(53.3)$ & $12(60.0)$ & $11(55.0)$ & 0.874 \\
Torso & $19(31.7)$ & $5(25.0)$ & $7(35.0)$ & 0.779 \\
Cerebellar & $17(28.3)$ & $7(35.0)$ & $9(40.0)$ & 0.594
\end{tabular}

${ }^{*}$ Test $x^{2}$ or Fisher's exact test; astatistically significant difference between RRMS and PPMS; ${ }^{b}$ statistically significant difference between SPMS and PPMS; RRMS: Relapse-remitting multiple sclerosis; SPMS: Secondary progressive multiple sclerosis; PPMS: Primary progressive multiple sclerosis; No.: Frequency. 
Finally, the Hospital Anxiety and Depression Scale (HADS) was used, also translated and validated for the Portuguese language, developed for hospitalized patients or those with chronic diseases, avoiding questions that can be attributed to both depression and symptoms of MS. This questionnaire is composed by 14 items, subdivided into 2 subscales, of which 7 assess the symptoms of depression (HADS-D) and 7 the symptoms of anxiety (HADS-A). It is considered that the score equal to or greater than 8 is a indicative of anxiety or depression, for this is the most sensitive score to detect the symptoms ${ }^{21}$.

Data were analyzed using the Statistical Package for the Social Sciences (SPSS) software v. 20.0 for Windows. The Kolmogorov-Smirnov test was used to analyze data distribution, and Bartlett's test, to verify the homogeneity of variances. The Kruskal-Wallis test was used to analyze the differences in DEFU scores among the subgroup of carriers, according to the clinical forms of the MS.

For categorical variables, Pearson's chi-squared test and Fisher's exact test were used.The Spearman's correlation index was used to analyze the correlation between the variables DEFU and MFIS-BR, DEFU and HADS-D, and DEFU and HADS-A. The significance level was considered at 5\%.

\section{RESULTS}

According to the mean scores obtained in the DEFU scale, patients with the PPMS clinical form presented worse perception of QoL $(66.90 \pm 3.47)$ when compared to SPMS (71.65 \pm 5.92$)$ and RRMS $(79.00 \pm 6.62)$, with a statistically significant difference $(\mathrm{p}<0.001)$. For all DEFU domains, higher mean scores were recorded in the RRMS clinical form, with a statistically significant difference when compared to the two other types. Only for the domain thinking and fatigue there was statistical difference between the SPMS and PPMS clinical forms (Table 3).

It was verified that, according to the scores obtained in the MFIS-BR scale, $63 \%$ of the individuals in the sample presented fatigue, with a mean score equal to $41.53 \pm 0.84$. Regarding the scores recorded in the HADS, $43 \%$ of the participants presented anxiety, and $48 \%$ depression. The mean score of HADS-A was $9.79 \pm 2.97$, and the HADS-D mean was $10.0 \pm 3.06$. There was a strong positive correlation between the DEFU and MFIS-BR scores ( $r=0.84$ ) showed in Figure 1 and a strong negative correlation between DEFU and HADS-A $(\mathrm{r}=-0.85)$ presented at Figure 2, and DEFU and HADS-D $(r=-0.82)$ as shown in Figure 3.
Table 3. DEFU scale domains by clinical form of the disease

\begin{tabular}{|c|c|c|c|c|}
\hline \multirow{3}{*}{ DEFU Domains } & \multicolumn{3}{|c|}{ Clinical form of the disease } & \multirow[b]{3}{*}{ p-value* } \\
\hline & RRMS & SPMS & PPMS & \\
\hline & Mean $\pm S D$ & Mean $\pm S D$ & Mean \pm SD & \\
\hline Mobility & $14.08 \pm 1.27$ & $12.75 \pm 1.33$ & $11.95 \pm 0.94$ & $<0.001^{a, b}$ \\
\hline Symptoms & $12.00 \pm 1.17$ & $10.85 \pm 0.81$ & $10.20 \pm 0.41$ & $<0.001^{a, b}$ \\
\hline Emotional well-being & $9.35 \pm 0.93$ & $8.15 \pm 0.87$ & $7.55 \pm 0.51$ & $<0.001^{a, b}$ \\
\hline General Contentment & $15.56 \pm 1.21$ & $14.2 \pm 1.00$ & $13.4 \pm 0.59$ & $<0.001^{a, b}$ \\
\hline Thinking and fatigue & $13.43 \pm 1.18$ & $12.25 \pm 1.40$ & $11.2 \pm 0.83$ & $<0.001^{a, b, c}$ \\
\hline $\begin{array}{l}\text { Family/Social well- } \\
\text { being }\end{array}$ & $14.56 \pm 1.06$ & $13.45 \pm 0.75$ & $12.6 \pm 0.59$ & $<0.001^{a, b}$ \\
\hline
\end{tabular}
Primary progressive multiple sclerosis; SD: Standard deviation.

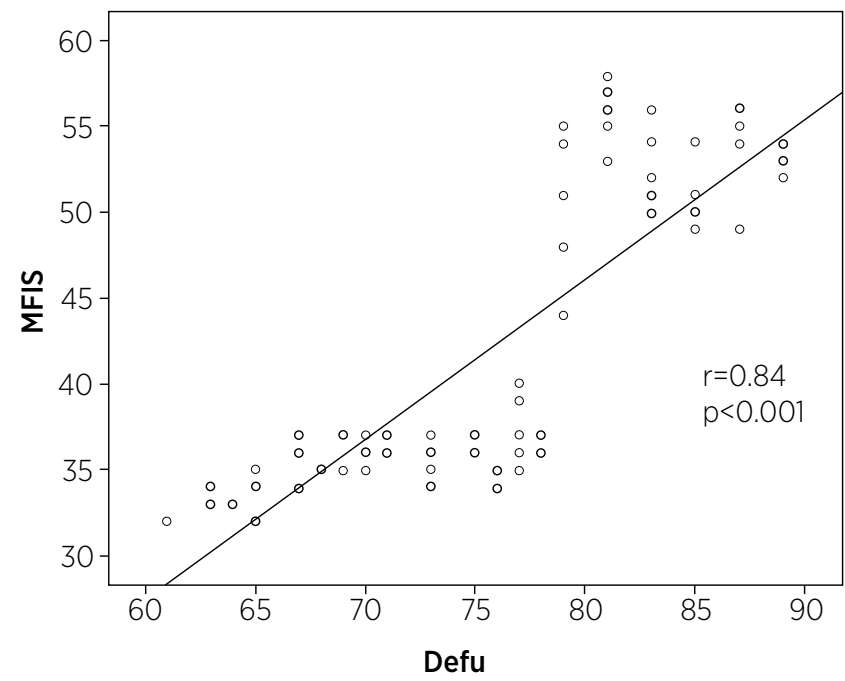

Figure 1. Correlation between DEFU and MFIS-BR scores r: Spearman's correlation

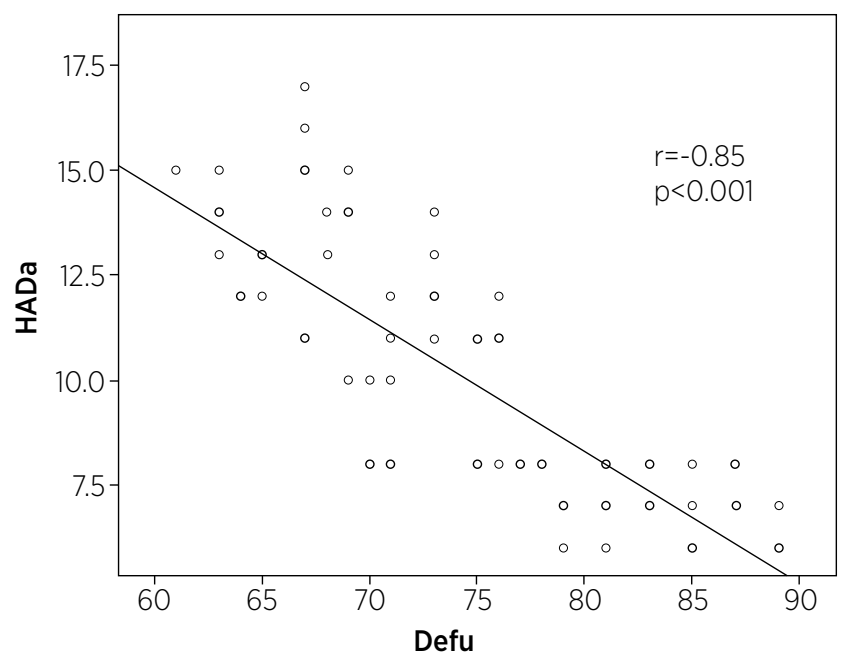

Figure 2. Correlation between DEFU and HADS-A scores $r$ : Spearman's correlation 


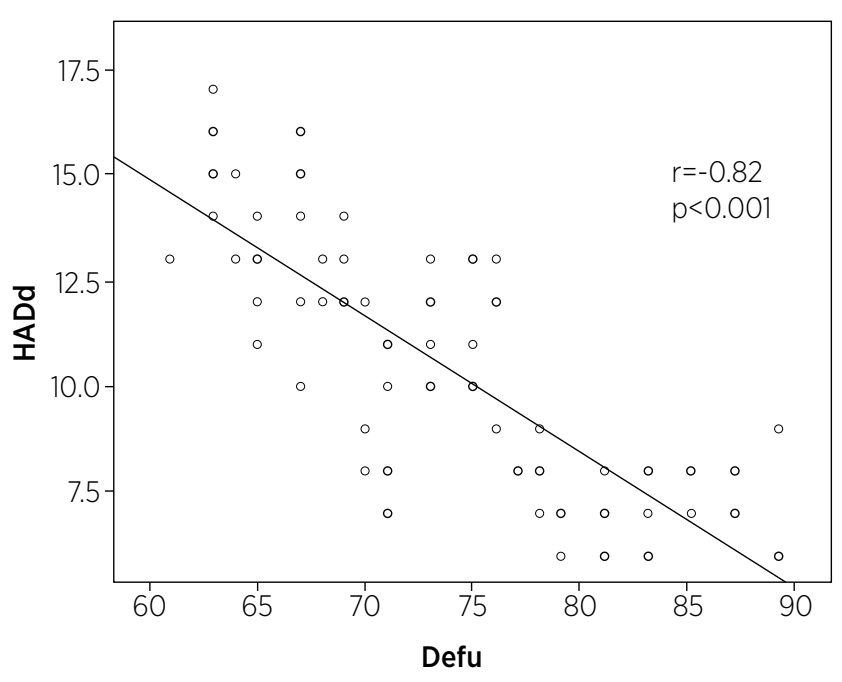

Figure 3. Correlation between DEFU and HADS-D scores r: Spearman's correlation

\section{DISCUSSION}

This study aims to assess the perception of $\mathrm{QoL}$ in patients with MS and to verify if the disease is associated with fatigue, anxiety and depression. The results suggest that individuals with MS experience decreased $\mathrm{QoL}$ perception. Evidence of previous research corroborate this finding and emphasize its association with the presence of fatigue and psychological symptoms ${ }^{22-27}$.

It is believed that people with MS present a reduction in the perception of QoL due to the clinical alterations of the disease and the side effects of the medications used, being associated with the presence of fatigue, anxiety and depression.

It is evident that patients with this disease have a wide range of initial and evolutionary symptoms/signs that affect their QoL. In this study, was registered an association between the presence of initial symptoms/signs with sping cord origin and the clinical form of PPMS. Spinal cord involvement can represent an important marker of chronicity and worse prognosis of this disease, which seems true, since individuals with PPMS had lower mean score in the DEFU scale when compared to individuals with the other forms ${ }^{28}$.

For all domains of the DEFU scale, lower mean scores were recorded in individuals with progressive clinical forms, since there are no obvious remissions in these cases, with the most significant deficits in comparison with those who have periods of remission. The domains related to physical aspects seem to be associated with fatigue, depression and anxiety ${ }^{29-31}$.
Fatigue was recorded in $63 \%$ of the study participants. Due to the damage in different regions of the brain, thinking and activities require greater energy than before, besides the greater need for strength to perform physical activities by the fact that the muscles with spasticity work against each other ${ }^{32}$. The demyelination makes the action of sending signals more difficult for neurons, and it is necessary to increase neuronal activity in cell tissues to compensate for this deficit, which gradually leads to weakness of physical capacities and results in the exhaustion of physical components in patients with $\mathrm{MS}^{33}$.

Anxiety was recorded in $43 \%$ of the patients with MS in the research. Previous studies have confirmed an association between anxiety and a reduction in the perception of QoL ${ }^{34,35}$. The anxiety of patients with MS can be explained by the theory of natural etiology or by biobehavioral approaches, which consider anxiety as an endogenous product that is created to face dangerous stimuli and is naturally produced in situations which the self is in danger - a mechanism that leads to a reduction in physiological functions and, therefore, decrease in the indicators associated with QoL in patients ${ }^{31}$.

Depression was recorded in $48 \%$ of the patients in the sample. The literature reports that depression is a significant predictor for the mental aspects that compose the perception of $\mathrm{QoL}^{36-38}$. The depression harms the motivation, interest and collaboration of the patient and, consequently, may affect the emotional state, personal satisfaction and social situation. Another interpretation is that depression can distort people's views on the world and their health, and change them in a way that deteriorates their assessment of themselves ${ }^{39}$.

One of the results of depression is the sensation of lack of energy, which negatively influences the patient's ability to withstand physical pressures. It is probably associated with focal demyelinating lesions and immune system malfunction ${ }^{40}$. These complications can lead to functional limitations and generalized disorders in physical and psycho-emotional components of QoL.

The study did not consider the level of disease severity and the family/social support style, factors that may influence the symptoms presented and in QoL perception of patients with MS. Some data presented are self-reported, which increases the possibility of biased responses. Another limitation of this research is the reduced size of the sample that may affect the results. It is suggested a prudent generalization of the results. 
It is also suggested the realization of future research that take into consideration possible mechanisms contributing to the alteration of patients with MS QoL, as followup with an interdisciplinary health team, including the realization of physical therapeutic and psycho-therapeutic treatment, quality of family/social support, employment and levels of coping.

\section{FINAL CONSIDERATIONS}

The decrease in the perception of QoL in patients with MS is more critical in the progressive forms of the disease and it is associated with the presence of fatigue, depression and anxiety.

\section{REFERENCES}

1. Garg N, Smith TW. An update on immunopathogenesis, diagnosis, and treatment of multiple sclerosis. Brain Behav. 2015;5(9):e00362. doi: 10.1002/brb3.362

2. Marques VD, Passos GR, Mendes MF, Callegaro D, LanaPeixoto MA, Comini-Frota ER, et al. Brazilian consensus for the treatment of multiple sclerosis: Brazilian Academy of Neurology and Brazilian Committee on Treatment and Research in Multiple Sclerosis. Arq Neuropsiquiatr. 2018;76(8):539-54. doi: 10.1590/0004-282×20180078

3. Thompson AJ, Banwell BL, Barkhof F, Carrol WM, Coetzee T, Comi G, et al. Diagnosis of multiple sclerosis: 2017 revisions of the McDonald criteria. Lancet Neurol. 2018;17(2):162-73. doi: 10.1016/S1474-4422(17)30470-2

4. Tintore M, Rovira À, Río J, Otero-Romero S, Arrambide G, Tur C, et al. Defining high, medium and low impact prognostic factors for developing multiple sclerosis. Brain. 2015;138(7):1863-74. doi: 10.1093/brain/awv105

5. Raggi A, Covelli V, Schiavolin S, Scaratti C, Leonardi M, Willems M. Work-related problems in multiple sclerosis: a literature review on its associates and determinants. Disabil Rehabil. 2016;38(10):936-44. doi: 10.3109/09638288.2015.1070295

6. Rae-Grant A, Bennett A, Sanders AE, Phipps M, Cheng E, Bever C. Quality improvement in neurology: multiple sclerosis quality measures: executive summary. Neurology. 2015;85(21):1904-8. doi: 10.1212/WNL.0000000000001965

7. Ysrraelit MC, Fiol MP, Gaitán MI, Correale J. Quality of life assessment in multiple sclerosis: different perception between patients and neurologists. Front Neurol. 2018;8:729. doi: 10.3389/fneur.2017.00729

8. Manjaly ZM, Harrison NA, Critchley HD, Do CT, Stefanics G, Wenderoth $\mathrm{N}$. et al. Pathophysiological and cognitive mechanisms of fatigue in multiple sclerosis. J Neurol Neurosurg Psychiatry. 2019;90(6):642-51. doi: 10.1136/jnnp-2018-320050
9. Thompson AJ, Baranzini SE, Geurts J, Hemmer B, Ciccarelli O. Multiple sclerosis. Lancet. 2018;391(10130):1622-36. doi: 10.1016/ S0140-6736(18)30481-1

10. Reich DS, Lucchinetti CF, Calabresi PA. Multiple sclerosis. N Engl J Med. 2018;378:169-80. doi: 10.1056/NEJMra1401483

11. Brownlee WJ, Hardy TA, Fazekas F, Miller DH. Diagnosis of multiple sclerosis: progress and challenges. Lancet. 2017;389(10076):1336-46. doi: 10.1016/S0140-6736(16)30959-X

12. Comini-Frota ER, Vasconcelos CCF, Mendes MF. Guideline for multiple sclerosis treatment in Brazil: consensus from the Neuroimmunology Scientific Department of the Brazilian Academy of Neurology. Arq Neuropsiquiatr. 2017;75(1):57-65. doi: 10.1590/0004-282×20160185

13. Penner IK, Paul F. Fatigue as a symptom or comorbidity of neurological diseases. Nat Rev Neurol. 2017;13(11):662-75. doi: 10.1038/nrneurol.2017.117

14. Tauil CB, Grippe TC, Dias RM, Dias-Carneiro RPC, Carneiro NM, Aguilar ACR, et al. Suicidal ideation, anxiety, and depression in patients with multiple sclerosis. Arq Neuropsiquiatr. 2018;76(5):296-301. doi: 10.1590/0004-282X20180036

15. Finkelsztejn A, Lopes JS, Noal J, Finkelsztejn JM. The prevalence of multiple sclerosis in Santa Maria, Rio Grande do Sul, Brazil. Arq Neuropsiquiatr. 2014;72(2):104-6. doi: 10.1590/0004-282X20130216

16. Elbers RY, Rietberg MB, Van Wegen EE, Verhoef J, Kramer SF, Terwee CB, et al. Self-report fatigue questionnaires in multiple sclerosis, Parkinson's disease and stroke: a systematic review of measurement properties. Qual Life Res. 2012;21(6):925-44. doi: 10.1007/s11136-011-0009-2

17. Jones SMW, Salem R, Amtmann D. Somatic symptoms of depression and anxiety in people with multiple sclerosis. Int J MS Care. 2018;20(3):145-52. doi: 10.7224/1537-2073.2017-069

18. Young-Blood MR, Chirichela IA, Pucci CR Filho, Camargo CHF, Fonseca RCV. Ansiedade e depressão em pacientes com esclerose múltipla. PsicoFAE. 2016;5(1):31-46.

19. Mendes MF, Balsimelli S, Stangehaus G, Tilbery CP. Validação de escala de determinação funcional da qualidade de vida na esclerose múltipla para a língua portuguesa. Arq Neuropsiquiatr. 2004;62(1):108-13. doi: 10.1590/S0004-282X2004000100019

20. Pavan K, Schmidt K, Marangoni B, Mendes MF, Tilbery CP, Lianza S. Esclerose múltipla: adaptação transcultural e validação da escala modificada de impacto de fadiga. Arq Neuropsiquiatr. 2007;65(3):669-73. doi: 10.1590/S0004-282X2007000400024

21. Botega NJ, Bio MR, Zomignani MA, Garcia C Jr, Pereira WAB. Transtornos do humor em enfermaria de clínica médica e validação da escala de medida (HAD) de ansiedade e depressão. Rev Saude Publica. 1995;29(5):355-63. doi: 10.1590/ S0034-89101995000500004

22. Morrow SA. Anxiety is more important than depression in MS - Yes. Mult Scler J. 2018;24(4):440-1. doi: 10.1177/1352458517751652

23. Al-Dughmi M, Siengsukon CF. The relationship between sleep quality and perceived fatigue measured using the neurological fatigue index in people with multiple sclerosis. Neurol Res. 2016;38(11):943-9. doi: 10.1080/01616412.2016.1232014

24. Lysandropoulos AP, Havrdova E, ParadigMS Group. 'Hidden' factors influencing quality of life in patients with 
multiple sclerosis. Eur J Neurol. 2015;22(Suppl 2):28-33. doi: 10.1111/ene.12801

25. Fernández-Muñoz JJ, Morón-Verdasco A, Cigarán-Méndez M, Muñoz-Hellín E, Pérez-de-Heredia-Torres M, Fernández-de-lasPeñas C. Disability, quality of life, personality, cognitive and psychological variables associated with fatigue in patients with multiple sclerosis. Acta Neurol Scand. 2015;132(2):118-24. doi: 10.1111/ane. 12370

26. Salehi R, Shakhi K, Khiavi FF. Association between disability and quality of life in multiple sclerosis patients in Ahvaz, Iran. Mater Sociomed. 2016;28(3):215-9. doi: 10.5455/msm.2016.28.215-219

27. Baumstarck K, Pelletier J, Boucekine M, Auquier P, MusiQoL Study Group. Predictors of quality of life in patients with relapsingremitting multiple sclerosis: a 2-year longitudinal study. Rev Neurol (Paris). 2015;171(2):173-80. doi: 10.1016/j.neurol.2014.09.005

28. Abdelhak A, Weber MS, Tumani H. Primary progressive multiple sclerosis: putting together the puzzle. Front Neurol. 2017;8:234. doi: 10.3389/fneur.2017.00234

29. Boeschoten RE, Braamse AMJ, Beekman ATF, Cuijpers P, van Oppen P, Dekker J, et al. Prevalence of depression and anxiety in multiple sclerosis: a systematic review and meta-analysis. J Neurol Sci. 2017;372:331-41. doi: 10.1016/j.jns.2016.11.067

30. Nogueira IC, Porto ACP, Silva EG, Melo PO, Belchior LD, Loiola LMCV, et al. Avaliação da ansiedade, depressão e qualidade de vida em pacientes com esclerose múltipla. Rev Inspirar Mov Saúde. 2017;14(3):6-10.

31. Salehpoor G, Rezaei S, Hosseininezhad M. Quality of life in multiple sclerosis (MS) and role of fatigue, depression, anxiety, and stress: a bicenter study from north of Iran. Iran J Nurs Midwifery Res. 2014;19(6):593-9.

32. Milinis K, Tennant A, Young CA, TONIC study group. Spasticity in multiple sclerosis: associations with impairments and overall quality of life. Mult Scler Relat Disord. 2016;5:34-9. doi: 10.1016/j.msard.2015.10.007

33. Lee JY, Biemond M, Petratos S. Axonal degeneration in multiple sclerosis: defining therapeutic targets by identifying the causes of pathology. Neurodegener Dis Manag. 2015;5(6):527-48. doi: 10.2217/nmt.15.50

34. Butler E, Matcham F, Chalder T. A systematic review of anxiety amongst people with multiple sclerosis. Mult Scler Relat Disord. 2016:10:145-68. doi: 10.1016/j.msard.2016.10.003

35. Goretti B, Viterbo RG, Portaccio E, Niccolai C, Hakiki B, Piscolla $E$, et al. Anxiety state affects information processing speed in patients with multiple sclerosis. Neurol Sci. 2014;35(4):559-63. doi: 10.1007/s10072-013-1544-0

36. Berzins SA, Bulloch AG, Burton JM, Dobson KS, Fick GH, Patten $\mathrm{SB}$. Determinants and incidence of depression in multiple sclerosis: a prospective cohort study. J Psychosom Res. 2017;99:169-76. doi: 10.1016/j.jpsychores.2017.06.012

37. Alhazzani AA, Alqahtani MS, Ogran $\mathrm{H}$, Abuhawi OH, Asiri AY, Al-Hanash AM, et al. Depression severity and its predictors among multiple sclerosis patients in Saudi Arabia: a crosssectional study. Neuroimmunol Neuroinflammation. 2018;5:8. doi: 10.20517/2347-8659.2017.55

38. Kidd T, Carey N, Mold F, Westwood S, Miklaucich M, Konstantara $E$, et al. A systematic review of the effectiveness of selfmanagement interventions in people with multiple sclerosis at improving depression, anxiety and quality of life. PLoS One. 2017;12(10):e0185931. doi: 10.1371/journal.pone.0185931

39. Ben-Zacharia A. Screening for depression in adult patients with multiple sclerosis. J Mult Scler. 2015;2:140. doi: 10.4172/2376-0389.1000140

40. Akaishi T, Nakashima I, Misu T, Fujihara K, Aoki M. Depressive state and chronic fatigue in multiple sclerosis and neuromyelitis optica. J Neuroimmunol. 2015;283:70-3. doi: 10.1016/j.jneuroim.2015.05.007 